\title{
Correction to: Compaction of Aluminium Foil and Its Effect on Oxidation and Recycling Yield
}

Alicia Vallejo-Olivares, Harald Philipson, Mertol Gökelma,

Hans J. Roven, Trond Furu, Anne Kvithyld, and Gabriella Tranell

\section{Correction to:}

"Compaction of Aluminium Foil and Its Effect on Oxidation and Recycling Yield" in: L. Perander (ed.), Light Metals 2021, The Minerals, Metals \& Materials Series, https://doi.org/10.1007/978-3-030-65396-5_96

The original version of this chapter was published with incorrect values. On page no. 736. The line " $68.6 \% \mathrm{KCl}, 29.4 \%$ $\mathrm{NaCl}$ " has been updated as " $68.6 \% \mathrm{NaCl}, 29.4 \% \mathrm{KCl}$ ". The erratum chapter has been updated with the changes.

The updated version of this chapter can be found at https://doi.org/10.1007/978-3-030-65396-5_96 